\title{
Impact of Tax Benefits and Earnings Management on Capital structures Across V4 Countries
}

\author{
Elena Gregova ${ }^{1}$, Lubos Smrcka ${ }^{2}$, Lucia Michalkova ${ }^{1}$, \\ Lucia Svabova ${ }^{1}$
}

${ }^{1}$ University of Zilina, Faculty of Operation and Economics of Transport and Communications, Department of Economics, Univerzitna 1, 01026 Zilina, Slovakia, elena.gregova@fpedas.uniza.sk; lucia.michalkova@fpedas.uniza.sk; lucia.svabova@fpedas.uniza.sk

${ }^{2}$ University of Economics, Faculty of Business Administration, Department of Business Economics, W. Churchill Sq. 4, 13067 Prague 3, Czech Republic, smrckal@vse.cz

\begin{abstract}
The issue of capital structure is among the most commonly discussed fields within Corporate Finance Theory. By optimizing the capital structure, it is possible to achieve an increase in the company value and increase the company flexibility and competitiveness. Economists have, for more than half a century, seen tax benefits (tax shields) as a capital structure determinant. Nonetheless, leverage is also influenced by earnings management, which can significantly reduce information asymmetry, between stakeholders when used correctly. This paper examines the influence of the tax shield and earnings management on a corporate capital structure, in V4 countries. In order to determine the influence of the tax shield and earnings management, panel data model was used. Net sample consisted of 10627 companies from the V4 countries from 2014-2017. The results of the model indicate that corporate behavior in the area of capital structure follows Pecking order; short-term trade credit is the most commonly used liability. The interest tax shield is of little importance for deciding between debt and equity, while the non-debt tax shield is negatively correlated with debt. Furthermore, an inverse correlation between debt and earnings management, as measured by the modified Jones model, indicates that debt monitoring, reduces agent costs and reduces the application of earnings management techniques.
\end{abstract}

Keywords: tax advantage; earnings management; emerging economies; capital structure determinants; Visegrad countries 


\section{Introduction}

Capital Structure is believed to be one of the most discussed topics of corporate finance theory. Too high a level of debt may lead to increased credit risk, the low credibility of the company, increase the cost of capital (WACC) and risk of the company failure as reported by Siekelova et al. [1], Kovacova and Kliestik [2], Valaskova et al. [3] or Durica et al. [4]. Conversely, a conservative approach to indebtedness may reduce corporate competitiveness, ultimately reducing the benefit of equity holders. A balanced debt-to-equity ratio is a win-win strategy, as both sides (debt holders and equity holders) make the most of capital. Moreover, there is growth in both indicators of profitability (return on assets - ROA, return on equity - ROE) and improvement in indicators of financial condition of the company $[5,6]$.

Capital structure theories have been developed mainly in advanced economies, especially in the US. First, it is the theory of Modigliani and Miller [7], which was developed by Myers [8] and called the Trade-off theory. The balance between the tax advantage of debt and the cost of financial distress forms an optimal capital structure. The tax benefit of debt, called the tax shield, is the main motive of this theory and should explain the growth in corporate debt. The Pecking order theory developed by Myers and Majluf [9] is the second dominant theory of capital structure, which in turn states that the company's internal resources, as retained earnings, are the first source of funds, regardless of the relatively higher capital cost and no tax advantage. These theories of capital structure take into account only marginally the third entity of stakeholders: managers who are responsible for the key financial decisions of the company. Jensen and Meckling [10] built up the Agency cost theory that clarifies the position of managers in deciding on the capital structure so as to achieve the highest benefit at a given debt-to-equity ratio. Holthausen [11] states that debt holders, equity holders and business managers are rational and use all available means to achieve their goals, including earnings management. McKee [12] states that earnings management is a legal choice and reporting management to achieve stable, predictable outcome. Under accounting regulations in national form or international GAAP (IFRS), financial statements are influenced in order to achieve a positive image of the business and to achieve the set objectives of the business. The existence of earnings management may be a reason for the continuous growth of corporate debt. The tax shield enables to reduce the company tax burden by reducing the pre-tax profit and represents one of the earnings management techniques.

In this context we tried to investigate the impact of the tax shield and earnings management on the corporate capital structure in the V4 countries. Traditional capital structure determinants such as tangibility, liquidity, profitability, business growth, risk or enterprise size are investigated in many studies from developed countries [13-16]. On the other hand, studies on the capital structure are represented to a lesser extent than the previous ones and are mainly assessed by 
SMEs [17-21]. Earnings management as a determinant of the capital structure has been analyzed in only a few studies primarily focused on publicly traded companies such as An et al. [22], Nikoomaran et al. [23] or Naz et al. [24]. As Sundvik [25] states, earnings management is not only used by public companies to increase the market value of the stock, but also by non-traded companies to increase profits through tax planning. This study examines the influence of both different types of tax benefits and earnings management on the capital structure of enterprises regardless of the type of ownership structure (listed or non-listed company).

This study has the following structure: The paper begins with a look at the investigated theories of capital structure from the point of view of developed and developing countries with regard to the Visegrad countries. The literature review also provides a critical assessment of the interrelationship between earnings management and tax benefits (tax shields), together with an overview of earnings management research in the Central European region. The description of the methods used (longitudinal data model) together with the data description is the content of the third section. The discussion is focused on comparing the results of the model with the prevailing approaches to capital structure on a Central European scale. The last section clarifies the possible shortcomings of this approach, including proposals for future research in the field of capital structure and earnings management.

\section{Theoretical Background}

\subsection{Capital Structure in Developed and Emerging Countries}

This sub-chapter summarizes theoretical and empirical knowledge of the capital structure in developed countries. These findings are compared with results in emerging countries, especially in the V4 economies.

As mentioned in the Introduction, there are two basic capital structure theories that are frequently studied in the financial literature: Trade-off theory developed by Myers [8] and Pecking order theory proposed by Myers and Majluf [9]. Both these theories have been tested since their inception, but empirical results do not provide unambiguous confirmation of which of the theories is correct, i.e. how the capital structure determinants relate to the debt value. Schwarz and Aronson [26] were one of the first to confirm the Trade-off theory based on the assumption of a constant optimal debt, which was confirmed, for example, by the Czech Republic. Graham et al. [14] confirmed the validity of the theory through the negative relationship of the non-interest tax shield and the interest tax shield. Anderson and Caverhill [16] confirm the validity of Trade-off theory based on a direct correlation between debt and liquidity due to lower default risk and lower 
bankruptcy costs. Kamath [27] states that more than $80 \%$ of quoted companies use internal resources as retained earnings, for $75 \%$ of companies, debt is the second best option, and for $80 \%$ of companies, the least preferred option is to issue shares. Pecking-order theory has also been confirmed by Titman and Wessels [28], Bancel and Mittoo [29] or Rajan and Zingales [13].

However, several studies have produced ambiguous results. Antoniou et al. [30] used panel data for analysis; their results indicate the application of both theories in deciding on the capital structure, as debt is positively correlated with tangibility and size, but also inverse correlated with profitability or business growth. Eldomiaty and Ismail [15] show that businesses are influenced by external conditions when deciding on the capital structure. At low tax rates, an enterprise cannot reach a high tax shield and opts for internal resources; on the contrary, the high tax burden makes the debt more attractive.

The capital structure in Central European countries, together with other emerging economies, was investigated mainly, over the last thirty years, after the transition to a market economy. Booth et al. [18] compared the capital structure in both types of economies (developed and developing); they argue that there are no different firm-specific determinants, the different capital structure is given by country-specific factors (GDP, inflation). Nivorozkin [17], based on an analysis of five emerging countries, reports that debt in these countries is lower than in developed economies, but the effect of business factors may also be different in countries with the same institutional and legal roots (for example, Slovakia and the Czech Republic). Delacoure [31] has developed a modified Pecking order theory based on an examination of the capital structure in Russia, Poland, the Czech Republic and Slovakia. Equity is perceived as a free source of capital; cost of equity is not taken into account.

Bauer [32] used a sample of quoted enterprises from the V4 countries. The results indicate that managers prefer internal resources and Pecking order theory, which was also confirmed by the author's analysis of Czech companies [33]. Reznakova et al. [19] used panel data from more than a thousand Slovak enterprises for the period 2002-2007. The main results are inconsistent with the Trade-off theory, but the authors stress that none of the theories can fully explain the capital structure. Koralun-Bereznicka [34] used a sample of enterprises from 11 European countries, including Poland, the Czech Republic and Slovakia. This proves that Pecking order theory is supported by several determinants in regard to long-term debt, while short-term debt better explains Trade-off theory. Moreover, in addition to firm-specific factors, the industry along with the country have an important position.

Hernadi and Ormos [21] investigated the choice between equity and debt on a sample of Central and Eastern European countries, taking into account the V4. They note that, in terms of long-term indebtedness, company-specific factors are more important, while country-specific factors are more important for short-term 
indebtedness, which should mean that financial decisions in developed and emerging countries are increasingly converging. Qualitative research by the authors [35] confirms the significant role of Pecking order theory in the region; the frequency of responses supporting Trade-off theory was low which signaled minimal role of this theory. Hartwell and Malinowska [20] results support the findings of previous studies: Pecking order theory fully explains the behavior of similar companies. Companies quoted on the Warsaw Stock Exchange prefer and trade credit and short-term debt over long-term debt and bank loans, which give rise to the partial tax benefits of interest.

Recent research on capital structure in Central and Eastern European countries suggests that the corporate capital structure is not uniform despite similar macroeconomic conditions and / or economic developments. Stradowski and Schmidt [36] examining Czech, Polish, Hungarian and Greek companies note that while Hungarian and Greek companies prefer debt based on trade-off theory; the Czech market is more inclined to the conclusions of the pecking order approach. Polish companies have undecided behavior regarding debt or equity preferences; none of the investigated theories clearly describes the behavior of these companies. However, the authors note that the Hungarian market evidenced significant anomalies that distinguish it from the financial structure of other Central European countries. Ruckova and Stavarek [37] outlined the differences in debt preferences in different sizes of enterprises. Focusing on the region of Central and Eastern Europe, they pointed out that while large companies prefer equity in the first place and the Pecking-order approach, the financial policy of mediumsized companies does not show a clear preference for either capital structure policy.

Profitable farms in V4 from the sample by Fenyves et al. [38] do not rely on debt, which corresponds to the pecking order approach, with the exception of Slovakia, whose corporate behavior in this sector can be explained not only by the pecking order approach, but also by another theory with greater explanatory power. Similar results as [36] were achieved by Skulanova [39] in the mining sector. Moreover, she notes that the high debt ratio in the past tends to negatively affect future debt; this effect is low, but not negligible. The study by Kedzior et al. [40] refuted the widespread acceptance of the pecking order approach in Central European countries. Polish technology companies prefer debt (trade-off theory) in terms of external technology acquisition. On the other hand, companies with significant $R \& D$ activities are to a greater extent financed by internal resources in the order of retained earnings, share capital and debt. These conclusions do not support the pecking order theory, but its modification according to [31].

Building companies in Central Europe do not show a homogeneous dependence of debt use on return on equity [41]. Slovak companies have an indirect dependence of debt on the return of debt in the examined sector. However, the magnitude of the effect of debt on profitability is smaller than for the reverse relationship. Horvathova et al. [42], tested the impact of capital structure on corporate 
performance. A high share of equity (90\%) minimizes EVA entities; the increase in debt has a positive effect on this indicator as well as EVA equity. The optimal debt-to-equity ratio should be 20:80 in favor of equity, taking into account maximum performance and existing financial and credit risks. The risk of default increases with the growth of debt; The interconnectedness of both areas of corporate finance is reflected in the similarity between the explanatory variables of bankruptcy models and the determinants of capital structure. Kovacova et al. [43] notes that Slovak and Czech bankruptcy models prefer similar predictors, Hungarian and Polish models differ significantly from them (e.g. in the first two mentioned countries ROA and current ratio is more used, in Hungary ROE and quick ratio).

Czech companies consider the lack of internal funds as retained earnings to be the most important factor in debt policy [44]. Financial flexibility is more important for retail companies, manufacturing companies considered earnings and cash flow volatility more important. Campbell and Rogers [45] note that the high volatility of operating and investment cash flow also causes instability in the capital structure, and the capital structure is formed with respect to other variables (earnings volatility). In relation to cash flow volatility and debt policy, corporate governance has an indispensable role to play as investigated by [46]. Taking into account the theory of capital, market indebtedness is significantly more affected by the level of corporate governance than the book value of debt. Poor corporate governance was associated with high indebtedness in the surveyed companies in Eastern Europe, which confirms the results of further studies in this area [47] [48].

The studies mentioned above, show that there are systematic differences in capital structures not only in terms of industries, countries and their macroeconomic factors (tax policy), but also less researched factors of capital structure such as corporate governance and related earnings management.

\subsection{Earnings Management, Tax Shield and Sources of Tax Shield}

Earnings management is a complex issue dealing with the management and manipulation of profits with a view to show the company financial performance according to the ideas of the company management. Walker [49], unlike McKee [12], defines earnings management in a broader sense as: the use of managerial discretion over (within GAAP) accounting choices, earnings reporting choices, and real economic decisions to influence how underlying economic events are reflected in one or more measures of earnings. There may be several motives for earnings management. One of the most important reasons is income smoothing to create a consistent view of a financially efficient business. The value of the company can be optimized through earnings management, which means growth of shareholder returns and motivation of future shareholders. As Dopuch and Pincus [50] states, one of the motives is the tax advantage. An enterprise may use some 
tax-based profit management methods, such as the choice of capital structure, inventory management methods, asset depreciation method, or extending the use of $R \& D$ costs [51]. These methods are part of earnings management but also represent different forms of non-interest and interest tax shields.

The main source of the tax shield is the interest paid as described in Modigliani and Miller [7]. Due to the growth of corporate debt, especially in international companies, thin capitalization has been introduced. Buettner et al. [52] states that an enterprise is thin capitalized if the established debt-to-equity ratio is exceeded. When this threshold is exceeded, further interest paid is not tax deductible. The aim of these measures is to reduce tax evasion, in particular in the context of lending between related parties which cause base erosion and profit shifting. Bachman et al. [53] examined the impact of thin-capitalized rules on the tax shield and noted that highly indebted companies have significantly reduced the tax shield as a result of the rules on limiting the tax deductibility of interest. A non-interest tax shield arises from the existence of different types of tax relief and incentives. The most widespread source is the depreciation reported by McKee [12] as one of the most popular earnings management techniques. Keating and Zimmerman [54] have shown that managers are changing the depreciation policy due to changes in tax laws, poor performance or new investment opportunities. Greater flexibility in the choice of depreciation method (e.g. straight-line vs. accelerated depreciation) or depreciation periods extends the earnings management options and hence, the value of the tax shield.

Research and development costs are another source of the tax shield as well as earnings management. A study by Guidara and Boujelbene [55] evidences that high R\&D businesses have discretionary accruals significantly different from zero, unlike businesses with no R\&D and zero discretionary accruals. High R\&D indicates the existence of profit manipulation. Tahinakis [56], analyzing European businesses in times of recession, found that businesses are manipulating $R \& D$ to avoid reporting losses or declining returns, regardless of whether the economy is in recession or not.

Tax loss carry forward significantly affects the value of the tax shield as identified by Velez-Pareja [57]. Chludek [58] argues that there is a negative relationship between loss carry forward and market value in the case of loss-making companies. Huxley and Sidaoui [59] examined the effect of volatility on the value of investment portfolios in Peru. They note that adopting a more liberal net carry forward in the tax code could bring an increase in returns on the stock market. Herborn et al. [60] states that the value of tax loss carry forward may be influenced by earnings management. Loss carry forward is a tool of earnings management and provides investors with information about future profitability.

Desai and Dharmpala [61] argue that tax reductions can give business management justification for opportunistic behavior and misleading corporate investors. Hanlon and Slemrod [62] found investors worried about the 
interconnectivity between tax shields, misuse of management positions and profit manipulation. The result of their study is to reveal the negative market reaction (fall in stock prices) to the publication of a wide application of tax optimization in the company. Dhaliwal et al. [63] examined the interaction of earnings management and effective tax rate. The study states that corporations are lowering the effective interest rate forecast for the fourth quarter, which is explained by lowering tax-deductible costs by business management to meet analysts' forecasts and expectations of business shareholders. Guenther [64] states that businesses can increase profits through the deductibility of interest expense. There is an inverse relationship between the company's debt and profit, i.e. a large debt implies a low company profit and vice versa. In connection with corporate income tax, this means an increase in the tax liability in connection with the increase in profit before tax. Given these assumptions, an enterprise will manipulate profits in an effort to reduce its tax liability. Therefore, an increasing debt ratio indicates profit manipulation.

Research on earnings management in Central European countries suggests that the reasons for the application of these techniques are several, including more favorable debt financing conditions, growth in corporate value or bias in tax charges [65]. Kramarova [66], focusing on transfer pricing, notes that Slovak companies manage their profits downwards, but it is not possible to confirm a linear link between earnings management and tax avoidance, or between controlled transactions and tax avoidance. Downward earnings management in order to reduce tax liability is not only typical in Slovak economic conditions, but also in other V4 countries [67]. Kliestik et al. [68] emphasizes that accounting manipulations with profit are not random, but have a growing trend. Earnings management in Czech companies reached a break-even point in 2013, other Central European countries have the same trend in earnings management, but their break-even point was not until 2014.

In addition to tax avoidance, initial public offering is a common reason for applying profit manipulation techniques. Sosnowski [69] examining Polish listed companies found that earnings management is not aggressively applied before IPOs, but the conservative form is widespread in the examined sample. Slight accounting manipulations reduce the probability of issuing new shares and the sale of secondary shares is more frequent, especially if the company reports negative discretionary accruals. In another study [70], the author focused on IPOs related to private equity funds. There is no evidence that the level of discretionary accruals in PE-backed and other listed companies is different; these companies do not show a lower level of accounting manipulation than other companies. However, no significant differences in the level of earnings management were found even compared to other Central and Eastern European countries [71] [72]. Sajnog [73] also researched Polish listed companies focusing on another phenomenon of earnings management, namely executive compensation. Although a strong relationship between corporate performance and executive compensation is 
presented [74] [73] shows a positive but insignificant relationship between ROE and executive compensation, and an inverse relationship between ROS and the variable under study.

Another area of earnings management research in developing Central European countries is earnings management detection methods. There is no consensus as to which of the models is most suitable for detection. Callao, et al. [67] evaluated models of accrual earnings management from the perspective of developing Eastern European countries (Visegrad Four). Although, the modified Jones model [75] is one of the most widely used models, it does not provide sufficiently reliable results in the studied countries; other models should be more appropriate, e.g. [76] [77]. Kliestik et al. [78], on the other hand, recommend the modified Jones model as the most suitable in Central European countries. Polish companies manipulate profit the most, while Slovak companies the least. However, none of the forms of accrual earnings management (downward and upward) prevail. Strakova [79] investigated the conditions of use of more than 20 models of earnings management and notes that only seven models, including the modified Jones model, are suitable for application in the conditions of Central European economies.

\section{Research Methodology and Data}

The purpose of the study is to examine the influence of earnings management and tax shields on the corporate capital structure of V4 economies and to determine which of the capital structure theories explains more appropriate behavior of these companies. In view of the subject matter of this study, we have chosen to use Leverage as a dependent variable quantified as a debt to asset ratio called Total leverage (TLEV). Studies mentioned in the previous chapter show that there are several major determinants of capital structure in particular tangibility, liquidity, profitability along with others. Eight explanatory variables were selected to quantify the leverage of businesses, the effective tax rate as a tax shield proxy, discretionary accruals as proxy earnings management, and six traditional determinants of the capital structure. The algorithms for calculating variables, as a predicted correlation according to capital structure theories, are presented in Table 1.

Earnings management can be detected by Discretionary Accruals (DA), part of Total Accruals (TA) influenced by corporate managers. We chose a model created by Dechow et al. [75], usually called modified Jones model, which belongs to the most widely used earnings management models. To estimate Discretionary accruals, it is necessary to run a regression with dependent variable - Total accruals. The total accrual is estimated using the formula listed in Hoglund [80]. This model can be applied to both cross-sectional data and time series. 
Table 1

Formulae and predicted correlation of independent variables

\begin{tabular}{|c|c|c|c|c|}
\hline \multirow[b]{2}{*}{ Variable } & \multirow[b]{2}{*}{ Label } & \multirow[b]{2}{*}{ Formula } & \multicolumn{2}{|c|}{ Predicted correlation } \\
\hline & & & $\begin{array}{l}\text { Trade-off } \\
\text { theory }\end{array}$ & $\begin{array}{l}\text { Pecking } \\
\text { order } \\
\text { theory }\end{array}$ \\
\hline Tangibility & TANG & $\begin{array}{l}\text { Tangible Fixed Assets / Total } \\
\text { Assets }\end{array}$ & positive & negative \\
\hline Liquidity & LIQ & $\begin{array}{l}\text { Current Assets/Current } \\
\text { Liabilities }\end{array}$ & positive & negative \\
\hline Profitability & PROF & EBITDA/Total Assets & positive & negative \\
\hline Size & SIZE & $\ln$ (Turnover) & positive & negative \\
\hline Growth & GROWTH & $\begin{array}{l}\left(\text { Total Assets }_{\mathrm{t}}-\text { Total Assets }_{\mathrm{t}-1}\right) \\
\text { / Total Assets } \\
\mathrm{t}-1\end{array}$ & negative & positive \\
\hline Tax shield & TAX & Taxation/EBT & positive & unknown \\
\hline $\begin{array}{l}\text { Business } \\
\text { risk }\end{array}$ & RISK & $\begin{array}{l}\left(\text { EBITDA }_{t}-\text { EBITDA }_{t-}\right. \\
\left.{ }_{1}\right) / \text { EBITDA }_{t-1}\end{array}$ & negative & negative \\
\hline $\begin{array}{l}\text { Earnings } \\
\text { management }\end{array}$ & EM & $\begin{array}{l}\text { Discretionary accruals } \\
\text { quantified by the modified } \\
\text { Jones model }\end{array}$ & unknown & positive \\
\hline
\end{tabular}

The modified Jones model estimate Non-discretionary accruals (NDA), residuals are Discretionary accruals. In summary, DA estimate is given in Equations (1)-(3).

$$
\begin{gathered}
\mathrm{TA}=\Delta \mathrm{CA}-\Delta \mathrm{CL}-\Delta \text { Cash }+\Delta \mathrm{STD}-\text { Dep } \\
\frac{\mathrm{TA}_{\mathrm{it}}}{\mathrm{A}_{\mathrm{it}-1}}=\alpha_{0} \frac{1}{\mathrm{~A}_{\mathrm{it}-1}}+\alpha_{1} \frac{\Delta \mathrm{REV}_{\mathrm{it}}-\Delta \mathrm{REC}_{\mathrm{it}}}{\mathrm{A}_{\mathrm{it}-1}}+\alpha_{2} \frac{\mathrm{PPE}_{\mathrm{it}}}{\mathrm{A}_{\mathrm{it}-1}}+\varepsilon_{\mathrm{it}} \\
\mathrm{TA}=\mathrm{NDA}+\mathrm{DA}
\end{gathered}
$$

Where $\triangle C A$ - change in Current assets, $\triangle C L$ - change in Current liabilities, $\triangle C$ ash is change in Cash, $\triangle S T D$ - change in Short-term debt, Dep - Depreciation, $T A_{i t}$ Total accruals in year $t, A_{\mathrm{it}-1}$ - Assets in year $t-1, \Delta R E V_{i t}$ - change in Revenues, $\triangle R E C_{i t}$ is change in Receivables; $P P E_{i t}$ - Property, Plant and Equipment in year $t$.

Due to data that is cross-sectional and time-series, the longitudinal data model is appropriated to estimate the influence of these factors on leverage. There are two basic types of panel data models; random effect model and fixed effect model. Using the notation given in Greene [81], the fixed effect panel model is given, as follows:

$$
y_{i t}=z_{i}^{\prime} \alpha+x_{i t}^{\prime} \beta+\varepsilon_{i t}
$$

Where: $i=1, \ldots, n$ and $t=1, \ldots, T$

In addition to the $x_{i t}$ variables, the fixed effect model contains dummy variables $z_{i}$ expressing the subject to a dependent variable. For this reason, the $L S D V$ model was used to model fixed effects. On the other hand, the random effect model, 
which is estimated by $F G L S$ model, assumes that the selected subjects represent the entire population and the results of the model can be generalized to the whole population. One of the key and necessary assumptions is zero correlation between intercept (unobserved effects) and independent variables. To determine which model is appropriate, Hausman test is applied. The null hypothesis suggests that independent variables are uncorrelated with random effects (a random effect model is preferred). The fixed effect model is preferred as said by alternative hypothesis.

SAS Enterprise Guide (Regression Analysis of Panel Data task) was used to provide a panel data model. We have examined the overall significance by F-test, as the significance of the regression coefficients by t-test was examined. Variables were non-significant if their $\mathrm{p}$-value was greater than 0.05 (significance level). As mentioned above, very low collinearity is in panel data models; yet we have verified collinearity by correlation matrix and the auxiliary regression method proposed by Gujarati and Porter [82].

Amadeus database supplied data for the paper. Sampling criteria were adapted to the goal of this study, the company registered office in the one of V4 countries, the value of pre-tax profit of more than 100000 EUR and assets of more than 2000000 EUR in 2014-2017. We assume that in such enterprises tax shield is obtained and managers use earnings management techniques. These criteria were met by 19910 companies of V4. Data covers 2014-2017. The sample were checked for extreme values by Mahalanobis distance as the outliers may distort the results.

\section{Results and Discussion}

The analyze of a sample of business was the first step in creating a capital structure model. The Amadeus database provides information on more than fifty data from financial statements and more than thirty financial indicators and ratios. However, the sample contained many incomplete financial statements and unspecified financial ratios, so these data points had to be removed. Subsequently, 1033 outliers were removed according to the Mahalanobis distance procedure. Data cover years 2014-2017; based on the formulas in Table 1, the variables were quantified in only three years. The sample included 10627 enterprises (1608 Slovak, 4163 Czech, 2662 Polish and 2192 Hungarian enterprises) and 31881 observations. Summary statistics are listed in Table 2.

Slovak corporate total leverage is in average higher in than in other countries, but it does not exceed two thirds of the assets value, which is the limit value of the golden rule of risk compensation for riskier sectors. 
Table 2

Descriptive statistics of V4 company's financial indicators

\begin{tabular}{|l|l|l|l|l|}
\hline \multicolumn{3}{|l|}{ Slovakia } & \multicolumn{2}{l|}{ The Czech Republic } \\
\hline Variable & Mean & Std Dev & Mean & Std Dev \\
\hline TLEV & 0.5262 & 0.2543 & 0.3938 & 0.2352 \\
\hline TANG & 0.3714 & 0.2866 & 0.3852 & 0.2634 \\
\hline LIQ & 2.4568 & 3.2086 & 3.7732 & 4.4773 \\
\hline PROF & 0.1703 & 0.1160 & 0.1627 & 0.0949 \\
\hline SIZE & 9.2647 & 1.4233 & 9.3790 & 1.3597 \\
\hline GROWTH & 0.0638 & 0.1727 & 0.0932 & 0.1509 \\
\hline TAX & 0.2411 & 0.1234 & 0.2056 & 0.1082 \\
\hline RISK & 0.1212 & 0.5452 & 0.1325 & 0.4405 \\
\hline EM & 0.0027 & 0.1342 & 0.0019 & 0.1127 \\
\hline & Poland & & Hungary \\
\hline Variable & Mean & Std Dev & Mean & Std Dev \\
\hline TLEV & 0.4711 & 0.2143 & 0.4522 & 0.2247 \\
\hline TANG & 0.3920 & 0.2765 & 0.3318 & 0.2513 \\
\hline LIQ & 2.0684 & 1.9129 & 2.5352 & 2.8283 \\
\hline PROF & 0.1430 & 0.0889 & 0.1562 & 0.0970 \\
\hline SIZE & 9.6346 & 1.2175 & 9.5803 & 1.2511 \\
\hline GROWTH & 0.1062 & 0.1708 & 0.1010 & 0.1915 \\
\hline TAX & 0.2176 & 0.1253 & 0.0844 & 0.0649 \\
\hline RISK & 0.1337 & 0.4369 & 0.1538 & 0.5248 \\
\hline EM & 0.0042 & 0.1062 & 0.0065 & 0.1435 \\
\hline
\end{tabular}

All countries show a high level of liquidity, above the recommended values (1.52 ), indicating that the companies are financially sound and able to meet their obligations. It also indicates a higher percentage of the company's internal resources that can be used for financing. This assumption is also confirmed by the high average profitability.

In terms of business growth, Hungary shows more than $10 \%$ of average growth. On the other hand, this growth is highly volatile, which is demonstrated in Risk variable. Significant profit volatility was reflected in the positive value of the proxy for Earnings management. The average enterprise in this sample uses profit manipulation to increase reported profit and overestimate the enterprise. Managers try to smooth the income to create a better view of the business. The comparison between the countries shows that the increase in the risk of changes in operating profit increases earnings management indicator. The tax shield quantified by the effective tax rate describes the individual corporate tax rate. Average values in Slovakia, the Czech Republic and Poland are similar, much lower effective tax rate is reported in Hungarian companies. This indicator is derived from the statutory tax rate; in Hungary, the tax rate has been reduced to $9 \%$ since 2017. In other countries, the statutory tax rate ranges from 19 to $22 \%$. 
First of all, we checked the existence of multi-colinearity in the model. Gujarati and Porter [82] suggest 0.5 in absolute terms. We have created correlation matrices with explanatory variables for each country. All correlation coefficients are in all cases lower than 0.4 in absolute numbers, which means that there is a low degree of multi-colinearity in the sample that does not bias the model results. To confirm these findings, we also applied an auxiliary regression procedure that confirmed the previous conclusions. Subsequently, we formed econometric models of panel data, the results of the fixed effect models are reported in Table 3.

Table 3

Results of one-way fixed effect models

\begin{tabular}{|c|c|c|c|c|}
\hline \multirow{2}{*}{$\begin{array}{l}\begin{array}{l}\text { Parameter } \\
\text { estimates }\end{array} \\
\text { Variable } \\
\end{array}$} & \multicolumn{2}{|l|}{ Slovakia } & \multicolumn{2}{|c|}{ The Czech Republic } \\
\hline & \begin{tabular}{|l|} 
Estimate \\
\end{tabular} & $\operatorname{Pr}>|t|$ & Estimate & $\operatorname{Pr}>|t|$ \\
\hline TANG & 0.0261 & 0.2677 & 0.0500 & 0.0003 \\
\hline LIQ & -0.0113 & $<0.0001$ & -0.0068 & $<0.0001$ \\
\hline PROF & -0.3892 & $<0.0001$ & -0.2816 & $<0.0001$ \\
\hline SIZE & 0.0316 & $<0.0001$ & -0.0032 & 0.4701 \\
\hline GROWTH & 0.0623 & $<0.0001$ & 0.1012 & $<0.0001$ \\
\hline TAX & -0.0100 & 0.3320 & -0.0491 & $<0.0001$ \\
\hline RISK & 0.0095 & $<0.0001$ & 0.0125 & $<0.0001$ \\
\hline EM & -0.0662 & $<0.0001$ & -0.0623 & $<0.0001$ \\
\hline F test & \multicolumn{2}{|r|}{54.0951} & \multicolumn{2}{|r|}{62.3999} \\
\hline $\operatorname{Pr}>F$ & \multicolumn{2}{|r|}{$<0.0001$} & \multicolumn{2}{|r|}{$<0.0001$} \\
\hline R-Square & \multicolumn{2}{|r|}{0.965} & \multicolumn{2}{|r|}{0.969} \\
\hline Adj. R-Square & \multicolumn{2}{|r|}{0.947} & \multicolumn{2}{|r|}{0.953} \\
\hline $\begin{array}{l}\text { Parameter } \\
\text { estimates }\end{array}$ & \multicolumn{2}{|l|}{ Poland } & \multicolumn{2}{|l|}{ Hungary } \\
\hline Variable & Estimate & $\operatorname{Pr}>|t|$ & Estimate & $\operatorname{Pr}>|t|$ \\
\hline TANG & 0.0072 & 0.6055 & -0.0709 & 0.0029 \\
\hline LIQ & -0.0245 & $<0.0001$ & -0.0193 & $<0.0001$ \\
\hline PROF & -0.3733 & $<0.0001$ & -0.2088 & $<0.0001$ \\
\hline SIZE & 0.0048 & 0.2649 & -0.0481 & $<0.0001$ \\
\hline GROWTH & 0.0804 & $<0.0001$ & 0.0897 & $<0.0001$ \\
\hline TAX & -0.0140 & 0.0174 & -0.0261 & 0.3039 \\
\hline RISK & 0.0088 & $<0.0001$ & 0.0121 & $<0.0001$ \\
\hline EM & -0.0188 & 0.0012 & -0.1082 & $<0.0001$ \\
\hline F test & & 70.8584 & & 29.4523 \\
\hline $\operatorname{Pr}>F$ & & $<0.0001$ & & $<0.0001$ \\
\hline R-Square & & 0.973 & & 0.937 \\
\hline Adj. R-Square & & 0.959 & & 0.905 \\
\hline
\end{tabular}


All models are significant at 0.05 , with a coefficient of determination greater than $90 \%$. These values prove that the explanatory variables correctly describe the capital structure in the V4 countries. The model specification was verified by the Hausman specification test, for which we quantified the one-way random model. The p-values of the Hausman test were lower than 0.0001, therefore the null hypothesis (random model is correct) is rejected.

According to the results in Table 3, we can conclude that Slovak, Czech and Polish companies follow both above stated theories (Pecking-Order and Trade-off) with the predominant influence of Pecking order theory. Hungarian companies provide results confirming the use of internal resources as a first choice in asset financing. The prevailing influence of the Pecking order is along the line with the qualitative survey of Hernadi and Ormos [35]. Our other findings are most consistent with the results of Hernadi and Ormos [21] and Nivorozhkin [17]. Other studies gave the same results only in some indicators (mainly Profitability, Size, Tangibility): Reznakova, et al. [19], Bauer [32], Harwell and Malinowska [20], Rajan and Zingales [13] or Titman and Wessels [28]. On the contrary, the research of Koralun - Bereznicka [34] brings completely different results. One reason for the different results is the use of aggregated data, which can distort the results as the author notes.

Tax shield indicator is positively correlated with debt, which does not satisfy any of the theories examined. The reason for this relationship between variables is given by the liabilities structure of the companies in the sample. A detailed examination of liabilities revealed that the predominant component of liabilities (debt) is trade credit, which is not interest-bearing and is short-term. This substantiates previous results of Rahman et al. [83] who investigated the mutual substitution between bank financing and trade credit. If businesses have bank overdrafts, they also use trade credit to a greater extent, confirming the complementary theory of trade credit and bank credit. This implies that the tax shield indicator is largely made up of a non-interest tax shield. Debt and noninterest tax shield are inversely related confirming DeAngelo and Masulis [84] hypothesis that both types of tax shield are mutually substituting. In terms of the non-debt tax shield, the results concurred with the most of the existing studies [28] [32]. For this reason, we can agree with the results of the Delacoure [31] study. The importance of the interest tax shield in the V4 countries is low and businesses use mainly their own created resources or trade credit to finance the company because it is conspired as free source of financing.

Business risk is significantly direct correlated with the debt-to-assets. This result significantly differs from most of the previous findings about risk and capital structure. As the volatility of profit increases, so does the cost of debt, which should be reflected in lower future debt [58]. The positive relationship between debt and risk is due to the high percentage of short-term debt in corporations. There is a limited availability of the long-term debt in V4 economies because the banks are the predominant providers of long-term debt, which have high 
requirements on borrowers and capital adequacy [85]. As reported by Hudakova et al. [87], financial together with economic risk do not depend on the business size in Slovakia, although financial risk is a key risk factor for SMEs. Enterprises with volatile profits offset the need for capital by short-term debt. A negative correlation between corporate risk and debt was observed, for example, by Nivorozhkin [17].

Earnings management estimated by the discretionary accruals is negatively correlated with the company's debt. This result confirms the debt monitoring hypothesis. Agent costs can be reduced by debt monitoring, as confirmed by Fung and Goodwin [88] who analyzed the relationship between earnings management and short-term debt. Similar results were obtained by Naz et al. [24] or Tahir et al. [89]. Conversely, An et al. [22] or Nikoomaran et al. [23] found a positive relationship between them. With reference to the direct correlation between debt and risk, we can note that the volatility of profit increases the risk of financial distress likewise the cost of capital. Businesses acquire each additional unit of capital under stricter creditors' conditions. Such a situation reduces the possibility of applying earnings management because the financial statements are more analyzed and audited.

\section{Conclusions}

Choosing the correct balance of debt and equity is one of the key choices, for any business. This decision can substantially affect a company's future financial performance, as well as, the benefits for all of the stakeholders (creditors, equity holders and business managers). Through earnings management techniques, an enterprise can improve its financial standing, which should enable it to raise more debt, raise its tax shield and increase share values.

This paper investigated the impact of the tax shield and earnings management on the corporate capital structure of V4 economies. A panel data regression model was created using financial information on 19910 businesses from 2014-2017 regardless, of their listing status. Eight (8), firm-specific factors were used; 7 traditional indicators (tangibility, liquidity, profitability, size, growth, business risk and tax shield) and earnings management indicator. The results of the model suggest that CEE firms primarily use internal resources to finance capital, which is mainly indicated by the negative correlations between leverage and profitability and leverage and liquidity. The preference of short-term debt and trade credit can be viewed as a relevant capital structure factor. The interest tax shield does not create sufficient debt preference since managers make greater use of non-debt tax benefits. Earnings management is negatively correlated with debt, which is supported by the debt monitoring hypothesis.

Finally, it can be emphasized, that the model results contributed to addressing the shortcomings in the field of capital structure, as well as, earnings management. The findings of the model can be taken into account when developing the model for detecting earnings management. However, the limitations of this study are 
given by the variables used; another earnings management detection model may be used, earnings management in the view of capital structure at different stages of the life-cycle may be investigated, or a SME model may be developed in which profit manipulation techniques should be applied. The findings and limitations of the study suggest further directions and possibilities for future research, such as testing the modified pecking order theory [31] in CEE, investigating the impact of trade credit on capital structure risk, focus on more detailed research of the impact of earnings management on capital structure in risk sectors such as tourism and/or at different stages of the life-cycle.

\section{Acknowledgement}

The paper is an output of the scientific project VEGA 1/0210/19: Research of innovative attributes of quantitative and qualitative fundaments of the opportunistic earnings modeling.

\section{References}

[1] Siekelova, A., Kollar, B., \& Weissova, I. (2015) Impact of credit risk management. Procedia Economics and Finance, 26, pp. 325-331, https://doi.org/10.1016/S2212-5671(15)00860-6

[2] Kovacova, M., \& Kliestik, T. (2017) Logit and Probit application for the prediction of bankruptcy in Slovak companies. Equilibrium. Quarterly Journal of Economics and Economic Policy, 12(4), pp. 775-791, https://doi.org/10.24136/eq.v12i4.40

[3] Valaskova, K., Kliestik, T., \& Kovacova, M. (2018) Management of financial risks in Slovak enterprises using regression analysis. Oeconomia Copernicana, 9(1), pp. 105-121, https://doi.org/10.24136/oc.2018.006

[4] Durica, M., Podhorska, I., \& Durana, P. (2019) Business failure prediction using cart-based model: A case of Slovak companies. Ekonomickomanazerske spektrum, 13(1), pp. 51-61

[5] Valaskova, K., Lazaroiu, G., Olah, J., Siekelova, A., \& Lancova, B. (2019) How capital structure affects business valuation: A case study of Slovakia. Central European Business Review, 8(3), pp. 1-17, https://doi.org/10.18267/j.cebr.218

[6] Valaskova, K., Kliestikova, J., \& Krizanova, A. (2018) Consumer Perception of Private Label Products: An Empirical Research. Journal of Competitiveness, 10(3), pp. 149-163, https://doi.org/10.7441/joc.2018.03.10

[7] Modigliani F., \& Miller M. H. (1963) Corporate income taxes and the cost of capital. A correction. The American Economic Review, 53(3), pp. 433443

[8] Myers, S. C. (1984) The Capital Structure Puzzle. Journal of Finance, 39(3), pp. 575-92, https://doi.org/10.3386/ w1393 
[9] Myers, S. C., \& Majluf, N. S. (1984) Corporate Financing and Investment Decisions When Firms Have Information That Investors Do Not Have. Journal of Financial Economic, 13(2), pp. 187-221, https://doi.org/10.3386/w1396

[10] Jensen, M. C. \& Meckling, W. H. (1976) Theory of the firm: Managerial behavior, agency costs and ownership structure. Journal of Financial Economics, 3(4), pp. 305-360, https://doi.org/10.1016/0304405X(76)90026-X

[11] Holthausen, R. W. (1990) Accounting method choice: opportunistic behavior, efficient contracting, and information perspectives. Journal of Accounting and Economics, 12 (1), pp. 207-218, https://doi.org/10.1016/0165-4101(90)90047-8

[12] McKee, T. E. (2005) Earnings Management: An Executive Perspective. Indiana: Thomson

[13] Rajan, R. G. \& Zingales, L. (1995) What Do We Know about Capital Structure? Some Evidence from International Data, Journal of Finance, 50(5), pp. 1421-1460, https://doi.org/10.3386/w4875

[14] Graham, J. R., Lang, M. H., \& Shackelford, D. A. (2004) Employee stock options, corporate taxes, and debt policy. Journal of Finance, 59 (4), pp. 1585-1618, https://doi.org/10.1111/j.1540-6261.2004.00673.x

[15] Eldomiaty, T. I., \& Ismail, M. A. (2009) Modeling capital structure decisions in a transition market: empirical analysis of firms in Egypt. Review of Quantitative Finance and Accounting, 32(3), pp. 211-233, https://doi.org/10.1007/s11156-008-0091-x

[16] Anderson, R. W., \& Caverhill, A. (2012) Corporate Liquidity and Capital Structure. The Review of Financial Studies, 25(3), pp. 797-837, https://doi.org/10.1093/rfs/hhr103

[17] Nivorozhkin, E. (2005) Financing Choices of Firms in EU Accession Countries. Emerging Markets Review, 6(2), pp. 138-169, https://doi.org/10.1016/j.ememar.2004.10.002

[18] Booth, L., Aizavian, V., Demirguc - Kunt, A., \& Maksimovic, V. (2001) Capital structure in developing countries. Journal of Finance, 56(1), pp. 87130, https://doi.org/10.1111/0022-1082.00320

[19] Reznakova, M., Svoboda, P., \& Polednakova, A. (2010) Determinants of Capital Structure: Empirical Evidence from Slovakia. Ekonomický časopis/Journal of Economics, 58(3), pp. 237-250

[20] Hartwell, C. A., \& Malinowska, A. (2018) Firm-level and institutional determinants of corporate capital structure in Poland: New evidence from the Warsaw stock exchange. Finance a Uver - Czech Journal of Economics and Finance, 68 (2), pp. 120-143 
[21] Hernadi, P., \& Ormos, M. (2012) Capital structure and its choice in Central and Eastern Europe. Acta Oeconomica, 62(2), pp. 229-263, http://dx.doi.org/10.1556/AOecon.62.2012.2.5

[22] An, Z., Li, D., \& Yu, J. (2016) Earnings Management, Capital Structure, and the Role of Institutional Environments. Journal of Banking \& Finance, 68, pp. 131-152, https://doi.org/10.1016/j.jbankfin.2016.02.007

[23] Nikoomaram, H., Arabahmadi, F., \& Arabahmadi, A. (2016) The Relationship between Earning Management and Capital Structure. International Journal of Finance and Managerial Accounting, 1(1), pp. 5156

[24] Naz, I., Bhatti, K., Ghafoor, A., \& Khan, H. H. (2011) Impact of Firm Size and Capital Structure on Earnings Management: Evidence from Pakistan. International Journal of Contemporary Business Studies, 2(12), pp. 22-31

[25] Sundvik, D. (2017) A review of earnings management in private firms in response to the tax rate changes. Nordic Tax Journal, 2017 (1), pp. 151161, https://doi.org/10.1515/ntaxj-2017-0011

[26] Schwartz, E., \& Aronson, J. R. (1967) Some Surrogate Evidence in Support of the Concept of Optimal Financial Structure. The Journal of Finance, 22(1), pp. 10-18, https://doi.org/10.1111/j.1540-6261.1967.tb01650.x

[27] Kamath, R. R. (1977) Long-Term Financing Decisions: Views and Practices of Financial Managers of NYSE Firms. The Financial Review. 32(2), pp. 331-356, https://doi.org/10.1111/j.1540-6288.1997.tb00428.x

[28] Titman, S. \& Wessels, R. (1988) The Determinants of Capital Structure Choice. Journal of Finance, 43(1), pp. 1-19, https://doi.org/10.1111/j.15406261.1988.tb02585.x

[29] Bancel, F., \& Mitoo, U. R. (2004) Cross - country determinants of capital structure choice: a survey of European firms. Financial Management, 33(4), pp. 103-132

[30] Antoniou, A, Guney, Y., \& Paudyal, K. (2008) The Determinants of Capital Structure: Capital Market-Oriented versus Bank-Oriented Institutions. Journal of Financial and Quantitative Analysis, 43(1), pp. 59-92, https://doi.org/10.1017/S0022109000002751

[31] Delcoure, N. (2007) The determinants of capital structure in transitional economies. International Review of Economics and Finance, 16(3), pp. 400-415, http://dx.doi.org/10.1016/j.iref.2005.03.005

[32] Bauer, P. (2004) Capital structure of listed companies in Visegrad countries. Prague economic papers, 13(2), pp. 159-175, https://doi.org/10.18267/j.pep.237 
[33] Bauer, P. (2004) Determinants of Capital Structure: Empirical Evidence from the Czech Republic. Czech Journal of Economics and Finance (Finance a uver), 54(1-2), pp. 2-21

[34] Koralun - Bereznicka, J. (2018) Determinants of Capital Structure Across European Countries. In Jajuga K., Locarek-Junge H., Orlowski L. (eds.) Contemporary Trends and Challenges in Finance. Springer Proceedings in Business and Economics, Cham (Switzerland): Springer, pp. 199-208, https://doi.org/10.1007/978-3-319-76228-9_19

[35] Hernadi, P., \& Ormos, M. (2012) What Managers think of Capital Structure and How They Act: Evidence from Central and Eastern Europe. Baltic Journal of Economics, 12(2), pp. 47-71, https://doi.org/10.1080/1406099X.2012.10840517

[36] Stradowski, M., \& Schmidt, K. (2020) Firm specific determinants of capital structure in European advanced developing countries. Bank $i$ Kredyt, 51(3), pp. 263-292

[37] Ruckova, P., \& Stavarek, D. (2020) Are there differences in the use of debt capital in enterprises of different size? International Journal of Monetary Economics and Finance, 13(2), pp. 163-176, https://doi.org/10.1504/IJMEF.2020.107698

[38] Fenyves, V., Peto, K., Szenderak, J., \& Harangi-Rakos, M. (2020) The capital structure of agricultural enterprises in the Visegrad countries. Agricultural Economics-Czech, 66(4), pp. 160-167, https://doi.org/10.17221/285/2019-AGRICECON

[39] Skulanova, N. (2020) Impact of selected determinants on the financial structure of the mining companies in the selected countries. Review of Economic Perpectives, 20(2), pp. 197-205, https://doi.org/10.2478/revecp2020-0009

[40] Kedzior, M., Grabinska, B., Grabinski, K., \& Kedzior, D. (2020) Capital Structure Choices in Technology Firms: Empirical Results from Polish Listed Companies. Journal of Risk and Financial management, 13(9), 221, https://doi.org/10.3390/jrfm13090221

[41] Ruckova, P. (2015) Dependency of return on equity and use of finance sources in building companies in v4 countries. E\&M Economics and Management, 18(3), pp. 73-83, http://dx.doi.org/10.15240/tul/001/2015-3007

[42] Horvathova, J., Mokrisova, M., \& Dancisinova, L. (2018) Modelling of capital structure in relation to business performance maximization. Investment Management and Financial Innovations, 15(2), pp. 292-304, http://dx.doi.org/10.21511/imfi.15(2).2018.26

[43] Kovacova, M., Kliestik, T., Valaskova, K., Durana, P., \& Juhaszova, Z. (2019) Systematic review of variables applied in bankruptcy prediction 
models of Visegrad group countries. Oeconomia Copernicana, 10(4), 743772, https://doi.org/10.24136/oc.2019.034

[44] Stryckova, L. (2019) Debt policy of companies in Czech Republic. Journal of International Studies, 12(3), pp. 183-197, https://doi.org/10.14254/2071$8330.2019 / 12-3 / 15$

[45] Campbell, G., \& Rogers, M. (2018) Capital Structure Volatility in Europe. International Review of Financial Analysis, 55(C), pp. 128-139, https://doi.org/10.1016/j.irfa.2017.11.008

[46] Berke-Berga, A., \& Dovladbekova, I. (2019) Capital structure and corporate governance: evidence from eastern european listed companies. Polish Journal of Management Studies, 20(2), pp. 161-173, https://doi.org/10.17512/pjms.2019.20.2.14

[47] Jiraporn, P., Kim, J., Kim, Y. S., \& Kitsabunnarat, P. (2012) Capital structure and corporate governance quality: Evidence from the Institutional Shareholder Services (ISS). International Review of Economics \& Finance, 22(1), pp. 208-221, https://doi.org/10.1016/j.iref.2011.10.014

[48] Liao, L., Mukhherjee, T., Wang, W. (2015) Corporate governance and capital structure dynamics: an empirical study. Journal of Financial Research, 38(2), pp. 169-191, https://doi.org/10.1111/jfir.12057

[49] Walker, M. (2013) How far can we trust earnings numbers? What research tells us about earnings management. Accounting and Business Research, 43(4), pp. 445-481, https://doi.org/10.1080/00014788.2013.785823

[50] Dopuch, N., \& Pincus, M. (1988) Evidence on the Choice of Inventory Accounting Methods: LIFO versus FIFO. Journal of Accounting Research, 26(1), pp. 28-59, http://dx.doi.org/10.2307/2491112

[51] Roychowdhury, S. (2006) Earnings management through real activities manipulation, Journal of Accounting and Economics, 42(3), pp. 335-370, https://doi.org/10.1016/j.jacceco.2006.01.002

[52] Buettner, T., Overesch, M., Schreiber, U., \& Wamser, G. (2012) The impact of thin-capitalization rules on the capital structure of multinational firms. Journal of Public Economics, 96(11), pp. 930-938, https://doi.org/10.1016/j.jpubeco.2012.06.008

[53] Bachmann, C., Lahmann, A., \& Schuler, C. (2015) The Impact of ThinCapitalization and Earnings Stripping Rules in the EU-15 on the Tax Shield, paper presented at EFMA 2015 Annual Meeting, Amsterdam, Netherlands. Retrieved from: https://efmaefm.org/0EFMAMEETINGS/EFMA\%20 ANNUAL\%20MEETINGS/2015-Amsterdam/papers/EFMA2015_0089_ fullpaper.pdf 
[54] Keating, A. S, \& Zimmerman, J. (1999) Depreciation-policy changes: tax, earnings management, and investment opportunity incentives. Journal of Accouting and Economics, 28(3), pp. 359-389, https://doi.org/10.1016/S0165-4101(00)00004-5

[55] Guidara, R., \& Boujelbene, Y. (2015) R\&D-Based Earnings Management and Accounting Performance Motivation. International Journal of Academic Research in Accounting, Finance and Management Sciences, 4(2), pp. 81-93, http://dx.doi.org/10.6007/IJARAFMS/v4-i2/805

[56] Tahinakis, P. D. (2014) R\&D expenditures and earnings management: Evidence from Eurozone countries in crisis. The Journal of Economic Asymmetries, $11(\mathrm{C})$, pp.

104-119, https://doi.org/10.1016/j.jeca.2014.09.002

[57] Velez - Pareja, I. (2016) Tax shields, financial expenses and losses carried forward. Cuadernos de Economía, 35(69), pp. 663-689, http://dx.doi.org/10.15446/cuad.econ.v35n69.54352

[58] Chludek, A. K. (2011) Perceived versus Actual Cash Flow Implications of Deferred Taxes - An Analysis of Value Relevance and Reversal under IFRS. Journal of International Accounting Research, 10(1), pp. 1-25, https://doi.org/10.2308/jiar.2011.10.1.1

[59] Huxley, S. J., \& Sidaoui, M. (2018) Gaining Market Share in Emerging Markets Portfolios by Moderating Extreme Returns: The Case of Peru. Economics, Management, and Financial Markets, 13(3), pp. 37-55, https://doi.org/10.22381/EMFM13320182

[60] Herbohn, K., Tutticci, I., \& Khor, P. S. (2010) Changes in Unrecognized Deferred Tax Accruals from Carry-Forward Losses: Earnings Management or Signalling? Journal of Business Finance and Accounting, 37 (7-8), pp. 763-791, https://doi.org/10.1111/j.1468-5957.2010.02207.x

[61] Desai, M. A., \& Dharmapala, D. (2009) Earnings Management, Corporate Tax Shelters, and Book-Tax Alignment. National taxjournal, 62(1), pp. 169-186, http://dx.doi.org/10.2139/ssrn.884812

[62] Hanlon, M., \& Slemrod, J. (2009) What does tax aggressiveness signal? Evidence from stock price reactions to news about tax shelter involvement. Journal of Public Economics, 93(1/2), pp. 126-141, https://doi.org/10.1016/j.jpubeco.2008.09.004

[63] Dhaliwal, D. S., Gleason, C. A., \& Mills, L. F. (2010) Last-Chance Earnings Management: Using the Tax Expense to Meet Analysts' Forecasts. Comtemporary Accounting Research, 21(2), pp. 431-459, https://doi.org/10.1506/TFVV-UYT1-NNYT-1YFH

[64] Guenther, D. A. (1994) Earnings Management in Response to Corporate Tax Rate Changes: Evidence from the 1986 Tax Reform Act. The Accounting Review, 69(1), pp. 230-243 
[65] Kramarova, K., \& Valaskova, K. (2020) Application of chosen fraudulent detection technique in the Slovak business environment. SHS Web of Conferences, 74, 01019, https://doi.org/10.1051/shsconf/20207401019

[66] Kramarova, K. (2021) Transfer Pricing and Controlled Transactions in Connection with Earnings Management and Tax Avoidance. SHS Web of Conferences, 92, 02031, https://doi.org/10.1051/shsconf/20219202031

[67] Callao, S., Jarne, J. I., \& Wroblewski, D. (2017) Detecting earnings management investigation on different models measuring earnings management for emerging Eastern European countries. International Journal of Research - Granthaalayah, 5(11), pp. 222-259, http://doi.org/10.5281/zenodo.1095448

[68] Kliestik, T., Valaskova, K., Nica, E., Kovacova, M. \& Lazaroiu, G. (2020) Advanced methods of earnings management: monotonic trends and changepoints under spotlight in the Visegrad countries. Oeconomia Copernicana, 11(2), pp. 371-400, https://doi.org/10.24136/oc.2020.016

[69] Sosnowski, T. (2017) Earnings management and the floatation structure: empirical evidence from Polish IPOs. Equilibrium. Quarterly Journal of Economics and Economic Policy, 12(4), pp. 693-709, https://doi.org/10.24136/eq.v12i4.36

[70] Sosnowski, T. (2018). Earnings management in the private equity divestment process on Warsaw Stock Exchange. Equilibrium. Quarterly Journal of Economics and Economic Policy, 13(4), pp. 689-705, https://doi.org/10.24136/eq.2018.033

[71] Lindahl, F., \& Schadewitz, H. (2018) Accounting quality in Eastern Europe after communism. Journal of East-West Business, 24(1), pp. 24-49, https://doi.org/10.1080/10669868.2017.1403988

[72] Cherkasova, V., \& Radasi, D. (2017) Earnings quality and investment efficiency: evidence from Eastern Europe. Review of Economic Perspectives, 17(4), pp. 441-468, https://doi.org/10.1515/revecp-2017-0023

[73] Sajnog, A. R. (2019) Executive compensation and comprehensive income: evidence from Polish listed companies. Oeconomia Copernicana, 10(3), pp. 493-509. https://doi.org/10.24136/oc.2019.024

[74] Kato, T., \& Kubo, K. (2006) CEO compensation and firm performance in Japan: evidence from new panel data on individual CEO pay. Journal of Japanese and International Economies, 20(1) pp. 1-19, https://doi.org/10.1016/j.jjie.2004.05.003

[75] Dechow, P. M., Sloan, R. G., \& Sweeney, A. P. (1995) Detecting Earnings Management. The Accounting Review, 70(2), pp. 193-225 
[76] Jones, J. (1991) Earnings Management during Import Relief Investigations. Journal of Accounting Research, 29,(2), pp. 193-228, https://doi.org/10.2307/2491047

[77] Kasznik, R. (1999) On the association between voluntary disclosure and earnings management. Journal of Accounting Research, 37(1), pp. 57-81, https://doi.org/10.2307/2491396

[78] Kliestik, T., Belas, J., Valaskova, K., Nica, E., \& Durana, P. (2020): Earnings management in V4 countries: the evidence of earnings smoothing and inflating, Economic Research-Ekonomska Istraživanja, https://doi.org/10.1080/1331677X.2020.1831944

[79] Strakova, L. (2020) Earnings management in global backround. SHS Web of Conferences, 74, 01032, https://doi.org/10.1051/shsconf/20207401032

[80] Hoglund, H. (2012) Detecting earnings management with neural networks. Expert Systems with Applications, 39(10), pp. 9564-9570, https://doi.org/10.1016/j.eswa.2012.02.096

[81] Greene, W. H. (2011) Econometric Analysis. $7^{\text {th }}$ edition, New York: Pearson

[82] Gujarati, D. N., \& Porter, D. C. (2008) Basic Econometrics. $5^{\text {th }}$ Edition, New York: McGraw-Hill Education

[83] Rahman, A., Rozsa, Z., \& Cepel, M. (2018) Trade Credit and Bank Finance - Evidence from the Visegrad Group. Journal of Competitiveness, 10(3), pp. 132-148, https://doi.org/10.7441/joc.2018.03.09

[84] DeAngelo, H., \& Masulis, R. W. (1980) Optimal capital structure under corporate and personal taxation. Journal of financial economics, 8(1), pp. 3-27, https://doi.org/10.1016/0304-405X(80)90019-7

[85] Brabenec, T. (2010) Certain important aspects of cost contribution arrangements in financial management. World Academy of Science, Engineering and Technology, 43, pp. 921-932

[86] Emerling, I., \& Wojcik-Jurkiewicz, M. (2018) The risk associated with the replacement of traditional budget with performance budgeting in the public finance sector management. Ekonomicko-manazerske spektrum, 12(1), pp. $55-63$

[87] Hudakova, M., Masar, M., Luskova, M., \& Patak M. R. (2018) The Dependence of Perceived Business Risks on the Size of SMEs. Journal of Competitiveness, 10(4), pp. 54-69, https://doi.org/10.7441/joc.2018.04.04

[88] Fung, S. Y. K., \& Goodwin, J. (2013) Short-term debt maturity, monitoring and accruals-based earnings management. Journal of Contemporary Accounting and Economics, 9(1), pp. 67-82, https://doi.org/10.1016/j.jcae.2013.01.002 
[89] Tahir, S. H., Sabir, H. M., \& Shah, S. Z. A. (2011) Impact of Earnings Management on Capital Structure of Non- Financial Companies Listed On (KSE) Pakistan. Global Business \& Management Research. 3(1), pp. 96105 